\title{
Komparasi Efektivitas Model Pembelajaran TPS (Think Pairs Share) Dan NHT (Numbered Head Together) Di Tinjau Dari Hasil Belajar Pembelajaran Tematik Pada Siswa SD
}

\author{
Supriadi ${ }^{1}$, Endang Indarini ${ }^{2}$ \\ Program Studi Pendidikan Guru Sekolah Dasar, Universitas Kristen Satya Wacana, Salatiga, \\ Indonesia \\ E-mail 292016142@student.uksw.edu , endang.indarini@uksw.edu
}

\begin{abstract}
Abstrak. Penelitian ini bertujuan untuk mengetahui perbedaan efektivitas antara model pembelajaran Think Pairs Share dan Numbered Head Together dari berbagai penelitian eksperimen yang dipublikasikan terhadap hasil belajar pada pembelajaran tematik SD. Penelitian yang dilakukan merupakan penelitian meta analisis. Langkah pertama yang diterapkan pada penelitian ini ialah menentukan masalah kemudian mencari data penelitian jurnal diinternet yaitu melalui Google Cendekia. Sesuai dengan temuan pencarian data, maka peneliti menemukan 10 jurnal yang sesuai. Model pembelajaran Think Pair Share memperlihatkan peningkatan rata-rata sebesar 17,48\% lebih besar dari model pembelajaran Numbered Head Together yaitu sebesar 16,19\%. Uji prasyarat dengan menggunakan uji normalitas, uji homogenitas, dan uji linearitas dapat memperlihatkan bahwa kedua model pembelajaran dapat berdistribusi normal, homogen, dan linear. Uji normalitas dengan menggunakan teknik Shapiro-Wilk memperlihatkan bahwa nilai signifikasi >0,05. Uji homogenitas data pretest menunjukkan Sig. sebesar 0,887 > 0,05 sedangkan data posttest menunjukkan Sig. sebesar 0,058 $>0,05$. Uji linearitas kedua model pembelajaran menunjukkan nilai signifikasi $>0,05$. Uji Ancova dengan menggunakan Univariate memperlihatkan bahwa nilai signifikan 0,042<0,05 berarti bahwa $\mathrm{H}_{\mathrm{o}}$ ditolak dan $\mathrm{H}_{\mathrm{a}}$ diterima. Dari hasil yang didapatkan memperlihatkan bahwa adanya perbedaan yang signifikan. Kemudian pada uji Effect Size yang menunjukkan bahwa model pembelajaran Think Pair Share dan Numbered Head Together memberikan pengaruh tergolong sedang pada hasil belajar pembelajaran tematik.
\end{abstract}

Kata Kunci: Think Pair Share, Numbered Head Together, Hasil Belajar Pembelajaran Tematik.

\section{PENDAHULUAN}

Pendidikan merupakan sarana yang digunakan oleh seorang guru untuk mengembangkan potensi-potensi yang dimiliki oleh siswa melalui pembelajaran. Guru dan siswa merupakan bagian dari proses berjalannya pendidikan.

Dulu dalam proses pembelajaran guru lebih sering menerapkan model pembelajaran konvensional dengan pendekatan "Teacher Centered" yang merupakan kegiatan pembelajaran yang lebih didominasi oleh guru. Yang artinya hanya dapat membantu siswa mengembangkan aspek kognitifnya saja sedangkan dari aspek afektif dan psikomotoriknya tidak tercapai, kemudian model ini dirasa kurang efektif, maka diterapkanlah model pembelajaran tematik yang mampu membantu mengembangkan aspek kognitif, afektif dan psikomotorik siswa serta mempunyai pengaruh terhadap hasil belajar dalam kegiatan pembelajarannya.

Pembelajaran tematik merupakan kegiatan pembelajaran yang mampu menjadikan proses belajar mengajar menjadi bermakna bagi siswa, sehingga bisa memberikan pengalaman bagi siswa dan membuat proses pembelajaran menjadi lebih efektif serta menarik (Trianto, 2010 :83). Sementara itu menurut Suyanto (2013: 180) menyatakan bahwa pembelajaran tematik merupakan model pembelajaran yang melibatkan siswa dalam proses belajar secara aktif dalam proses pembelajaran, sehingga peserta didik dapat memperoleh pengalaman langsung dan terlatih untuk dapat menemukan sendiri berbagai pengetahuan yang dipelajarinya. Sesuai dengan pernyataan ahli diatas dapat disimpulkan bahwa pembelajaran tematik merupakan suatu 
kegiatan pembelajaran yang di dalamnya melibatkan guru dan siswa yang saling berinteraksi dalam proses pembelajaran tematik untuk mengembangkan kecerdasan yang dimiliki sehingga mampu untuk menncapai tujuan pendidikan. Pembelajaran tematik ini tentunya mempunyai pengaruh terhadap hasil belajar yang didapatkan oleh siswa.

Hasil belajar merupakan perubahan sikap yang dialami siswa dalam mengikuti proses pembelajaran yang terlihat dari aspek kognitif, afektif dan psikomotorik (Purwanto, 2010: 46). Sedangkan menurut Sudjana (2010: 22) menyatakan bahwa hasil belajar merupakan tingkat kemajuan yang dirasakan siswa setelah adanya interaksi dalam mengikuti proses pembelajaran. Sesuai pernyataan ahli diatas dapat disimpulkan bahwa hasil belajar adalah tingkat perubahan yang dialami oleh siswa dari aspek kognitif, afektif dan psikomotoriknya setelah menerima pengalaman dalam proses pembelajaran.

Dalam mengembangkan hasil belajar siswa pada pembelajaran tematik, hendaknya guru mampu menentukan dan menggunakan model pembelajaran yang efektif dalam proses pembelajaran. Pada saat ini banyak model pembelajaran yang dapat digunakan dalam kegiatan pembelajaran. Salah satunya ialah model pembelajaran Think Pair Share. Model pembelajaran Think Pair Share adalah salah satu pendekatan struktural dalam pembelajaran kooperatif. Dimana, siswa dikelompokkan secara berpasangan yang bertujuan untuk mengefektifkan proses belajar kelompok (Julianto dkk, 2011:37). Sementara itu, Trianto (2010: 81) menyatakan bahwa model pembelajaran Think Pairs Share merupakan model pembelajaran yang dibuat untuk dapat memberikan kesempatan bagaimana cara siswa berkomunikasi, berpikir kemudian bekerjasama dengan temannya. Langkahlangkah model pembelajaran Think Pairs Share yaitu: 1) Thinking (berpikir), 2) Pairing (berpasangan) dan 3) Sharing (berbagi). Selain model pembelajaran Think Pairs Share ada juga model pembelajaran Numbered Head Together. Model pembelajaran Numbered Head Together merupakan merupakan model pembelajaran yang memberikan penomoran pada setiap anggota kelompok yang telah dibentuk kemudian guru memanggil nomor yang telah diberikan kepada setiap anggota kelompok secara acak (Komalasari, 2010: 62). Selain itu, Kagan Dalam (Tampubolon, 2014: 94) menyatakan bahwa model pembelajaran Numbered Head Together merupakan pengembangan dari model pembelajaran Teams Games Tournament. Model pembelajaran Numbered Head Together memiliki ciri-ciri khusus, dimana dalam kelompok siswa menyelesaikan tugas dengan saling membagi ide atau gagasan dengan teman kelompoknya. Langkah-langkah model pembelajaran Numbered Head Together yaitu: 1) persiapan, 2) pembentukan kelompok, 3) menyediakan buku paket, 4) diskusi masalah, 5) penomoran, dan 6) memberikan kesimpulan. Dalam kegiatan pembelajaran kedua model pembelajaran ini selalu mempunyai hubungan dengan kehidupan sehari-hari, sehingga dapat membantu siswa dalam mengembangkan hasil belajarnya. Penelitian yang dilakukan oleh Yudha Popiyanto (2019) dengan menggunakan Model pembelajaran Think Pair Share terlihat adanya peningkatan hasil belajar pembelajaran tematik. Penelitian yang dilakukan oleh Komang Dina Yanti, Desak Putu Parmiti dan Ignatius I Wayan Suwatra (2016) dengan menggunakan Model pembelajaran Numbered Head Together terlihat adanya peningkatan hasil belajar pembelajaran tematik.

Dari penelitian yang telah dilakukan dengan menggunakan model pembelajaran Think Pair Share dan Numbered Head Together terlihat kalau kedua model pembelajaran tersebut efektif digunakan pada pembelajaran tematik untuk meningkatkan hasil belajar. Sehingga membuat keinginan untuk melaksanakan penelitian mengenai model pembelajaran Think Pair Share dan Numbered Head Together. Oleh karena itu, peneliti melakukan penelitian yang berjudul "Komparasi Efektivitas Model Pembelajaran TPS (Think Pairs Share) dan NHT (Numbered Head Together) Di Tinjau Dari Hasil Belajar Pembelajaran Tematik Pada Siswa SD". Penelitian ini dilaksanakan untuk mengetahui 
"Apakah Hasil Belajar Pembelajaran Tematik dengan Model TPS (Think Pairs Share) Dari Berbagai Penelitian Eksperimen Yang di Publikasikan Lebih efektif Dari NHT (Numbered Head Together)?".

\section{METODE PENELITIAN}

Penelitian yang dilakukan ialah meta analisis. Meta Analisis merupakan proses penelitian yang dapat dilakukan dengan kegiatan merangkum, mereview, dan menganalisis data penelitian yang sudah dilakukan oleh peneliti lain (Rahmat Alyakin Dachi, 2017 : 335). Dalam menentukan populasi dengan cara mencari jurnal online diinternet melalui Google Cendekia. Kata kunci yang digunakan dalam mencari jurnal ialah "Think Pair Share", "Numbered Head Together", dan "Hasil Belajar Pembelajaran Tematik". Dari penelusuran melalui kata kunci tersebut didapatkan beberapa jurnal yang sesuai dengan kriteria penelitian yang akan dilaksanakan itu terlihat dengan adanya data pretest dan posstest dalam bentuk skor presentase rata-rata dalam jurnal yang didapatkan. Instrumen data yang dipakai ialah dengan pemberian kode pada masing-masing jurnal yang diperoleh.

Teknik analisis data menggunakan uji prasyarat (uji normalitas, uji homogenitas, dan uji linearitas), uji Ancova menggunakan Univariate, dan menghitung Effect Size untuk melihat pengaruh model pembelajaran Think Pair Share dan Numbered Head Together terhadap hasil belajar pembelajaran tematik.

\section{HASIL DAN PEMBAHASAN}

Langkah awal yang diterapkan pada penelitian ini ialah menentukan masalah kemudian mencari data penelitian jurnal diinternet melalui Google Cendekia. Sesuai dengan temuan pencarian oleh peneliti menemukan 10 jurnal yang sesuai. Peneliti menemukan masing-masing 5 jurnal pada dua model pembelajaran yang digunakan. dimana 5 jurnal pada model pembelajaran Think Pair Share dan 5 jurnal untuk model pembelajaran Numbered Head Together. Data hasil analisis model pembelajaran Think Pair Share bisa dilihat pada tabel dibawah ini.
Tabel 1. Presentase Peningkatan Hasil Belajar Pembelajaran Tematik Dengan Model Pembelajaran Think Pair Share

\begin{tabular}{ccccc}
\hline \multirow{2}{*}{$N_{0}$} & & \multicolumn{3}{c}{ Presentase (\%) } \\
\cline { 3 - 5 } & Kode Data & Skor Pretest & Skor Posstest & Peningkatan \\
\hline 1 & $1 \mathrm{~A}$ & 67,48 & 79,23 & 11,75 \\
\hline 2 & $2 \mathrm{~A}$ & 56,36 & 74,97 & 18,61 \\
\hline 3 & $3 \mathrm{~A}$ & 53,61 & 81,94 & 28,33 \\
\hline 4 & $4 \mathrm{~A}$ & 14 & 24,80 & 10,8 \\
\hline 5 & $5 \mathrm{~A}$ & 63 & 80,25 & 17,25 \\
\hline & Rata-rata & 50,89 & 68,238 & 17,48 \\
\hline
\end{tabular}

Presentase rata-rata peningkatan hasil belajar pembelajaran tematik menggunakan model pembelajaran Think Pair Share dari skor terendah sebesar 10,8\% dan skor tertinggi sebesar 28,33\% dengan rata-rata sebesar $17,48 \%$. Data hasil analisis model pembelajaran Numbered Head Together bisa dilihat pada tabel dibawah ini.

Tabel 2. Presentase Peningkatan Hasil Belajar Pembelajaran Tematik dengan Model Pembelajaran Numbered Head Together

\begin{tabular}{ccccc}
\hline \multirow{2}{*}{ N $_{0}$} & Kode Data & \multicolumn{3}{c}{ Presentase (\%) } \\
\cline { 3 - 5 } & & Skor Pretest & Skor Posstest & Peningkatan \\
\hline 1 & 1B & 43,33 & 50 & 6,67 \\
\hline 2 & $2 \mathrm{~B}$ & 33,25 & 63,80 & 30,55 \\
\hline 3 & $3 \mathrm{~B}$ & 68,81 & 77,06 & 8,25 \\
\hline 4 & $4 \mathrm{~B}$ & 16,99 & 20,60 & 3,61 \\
\hline 5 & $5 \mathrm{~B}$ & 48,13 & 80 & 31,87 \\
\hline & Rata-rata & 42,102 & 58,92 & 16,19
\end{tabular}

Presentase rata-rata peningkatan hasil belajar pembelajaran tematik menggunakan model pembelajaran Numbered Head Together dari skor terendah sebesar 3,61\% skor tertinggi sebesar $30,55 \%$ dengan rata-rata sebesar $16,19 \%$. Sesuai dengan presentase skor pretest dan posstest sehingga bisa dikomparasikan antara model pembelajaran Think Pair Share dan Numbered Head Together. Komparasi bisa dilihat pada tabel dibawah ini.

Tabel 3. Komparasi Hasil Pengukuran Hasil Belajar Pembelajaran Tematik 


\begin{tabular}{|c|c|c|c|}
\hline \multirow{3}{*}{ Pengukuran } & \multicolumn{3}{|c|}{ Rata-Rata Skor (Meanl) } \\
\hline & Think Pain Share & Nunnbered Head & Selish \\
\hline & & Together" & \\
\hline Pretest & 50,89 & 42,102 & $8,788 \%$ \\
\hline Posstest & 68,238 & 58,92 & $9,318 \%$ \\
\hline
\end{tabular}

Sesuai dengan hasil komparasi rata-rata skor pada tabel diatas, rata-rata skor pretest antara model pembelajaran think pair share dan numbered head together mempunyai selisih 8,788\% dan posstest 9,318\%. Berikut ini adalah diagram komparasi data antara model pembelajaran think pair share dan numbered head together.

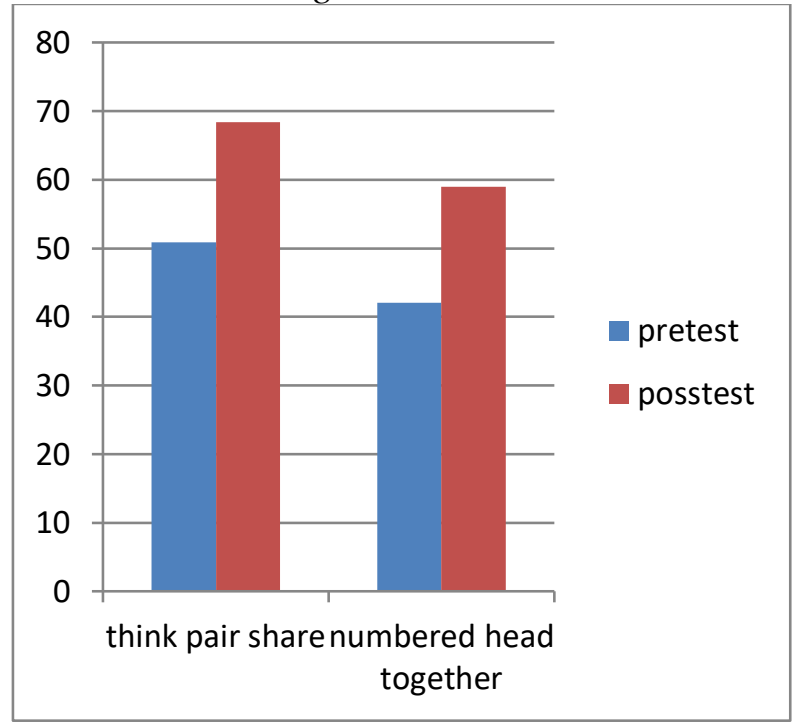

Diagram 1 Diagram Komparasi Data Antara Model Pembelajaran Think Pair Share dan Numbered Head Together

Sesuai dengan diagram diatas, dapat disimpulkan bahwa terdapat peningkatan dari skor pretest dan posstest pada model pembelajaran Think Pair Share dan Numbered Head Together

Tabel 4. Uji Normalitas Model pembelajaran Think Pair Share dan Numbered Head Together.

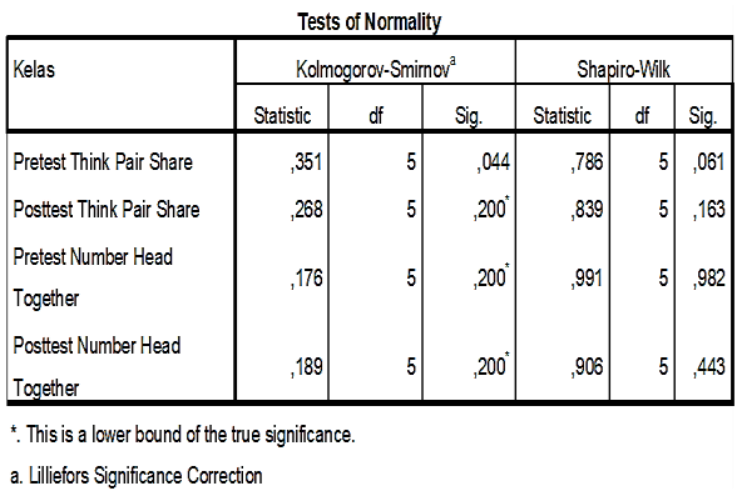

Sesuai dengan tabel diatas dapat dilihat hasil uji normalitas pretest dan posstest dari model pembelajaran Think Pair Share dan Numbered Head Together. Uji normalitas memakai data Shapiro-Wilk dengan berbantuan SPSS 20.0 for windows bisa diartikan kalau signifikasi > 0,05 maka data berdistribusi normal.

Tabel 5. Uji Homogenitas Skor Pretest Model Pembelajaran Think Pair Share dan Numbered Head Together

\begin{tabular}{|c|c|c|c|c|c|}
\hline & & Levene Statistic & df1 & $d: 2$ & Sig. \\
\hline \multirow{5}{*}{ Hasil Belajar } & Based on Mean & 022 & 1 & 8 & 887 \\
\hline & Based on Median &, 007 & 1 & 8 &, 937 \\
\hline & Based on Median and with & & & & \\
\hline & adjusted df & & & & \\
\hline & Based on trimmed mean &, 003 & 1 & 8 & 956 \\
\hline
\end{tabular}

Sesuai dengan tabel diatas, bisa dilihat hasil uji homogenitas skor pretest melalui metode Leven's Test dengan hasil rata-rata (Based on Mean) yang menunjukkan nilai signifikasi $0,887>0,05$ sehingga dapat disimpulan kalau data berdistribusi homogen.

Tabel 6. Uji Homogenitas Skor Posstest Model Pembelajaran Think Pair Share dan Numbered Head Together

\begin{tabular}{|c|c|c|c|c|c|}
\hline & & Levene Statistic & dif & $d t^{2}$ & Sig. \\
\hline \multirow{5}{*}{ Hasil Belajar } & Based on Mean & 4,878 & 1 & 8 &, 058 \\
\hline & Based on Median & 2,860 & 1 & 8 &, 129 \\
\hline & Based on Median and with & & & & \\
\hline & adjusted df & & & & \\
\hline & Based on trimmed mean & 4,545 & 1 & 8 &, 066 \\
\hline
\end{tabular}

Sesuai dengan tabel diatas, bisa dilihat hasil uji homogenitas skor posstest melalui metode Leven's Test dengan hasil rata-rata 
(Based on Mean) yang menunjukkan nilai signifikasi yaitu $0,058>0,05$ sehingga dapat disimpulkan kalau data berdistribusi homogen. Tabel 7. Uji linearitas skor pretest dan posstest Model pembelajaran Think Pair Share

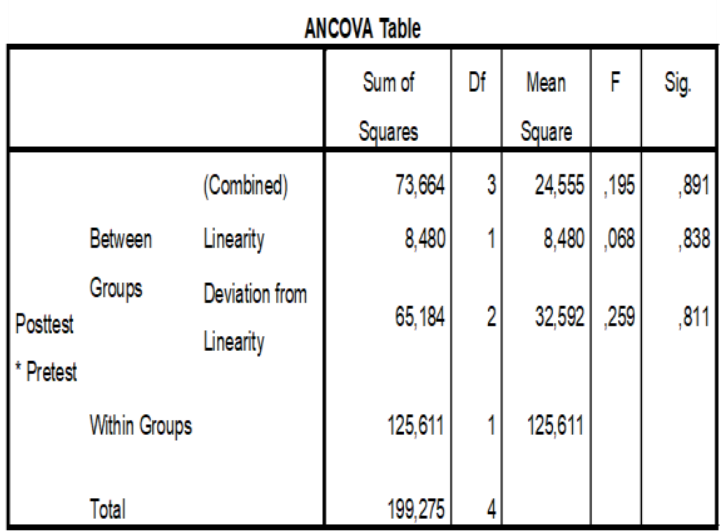

Sesuai dengan tabel diatas, bisa dilihat bahwa hasil uji linearitas skor pretest dan posstest model pembelajaran Think Pair Share dengan Deviation From Linearity yang menunjukkan nilai Sig. 0,811 >0,05 sehingga bisa disimpulkan kalau data mempunyai hubungan yang linear.

Tabel 8. Uji Linearitas Skor Pretest dan Posstest Model pembelajaran Numbered Head Together

\begin{tabular}{|c|c|c|c|c|c|c|c|}
\hline \multicolumn{8}{|c|}{ ANCOVA Table } \\
\hline & & & $\begin{array}{l}\text { Sum of } \\
\text { Squares }\end{array}$ & $d f$ & $\begin{array}{l}\text { Mean } \\
\text { Square }\end{array}$ & $F$ & Sig. \\
\hline \multirow{6}{*}{$\begin{array}{l}\text { Posttest * } \\
\text { Pretest }\end{array}$} & & (Combined) & 2258,941 & 3 & 752,980 & 7,908 & 254 \\
\hline & Between & Linearity & 1822,841 & 1 & 1822,841 & 19,143 &, 143 \\
\hline & Groups & Deviation from & \multirow{2}{*}{436,101} & \multirow{2}{*}{2} & \multirow{2}{*}{218,050} & \multirow{2}{*}{2,290} & \multirow{2}{*}{, 423} \\
\hline & & Linearity & & & & & \\
\hline & \multicolumn{2}{|c|}{ Within Groups } & 95,220 & 1 & \multirow[t]{2}{*}{95,220} & & \\
\hline & \multicolumn{2}{|l|}{ Total } & 2354,161 & 4 & & & \\
\hline
\end{tabular}

Sesuai dengan tabel diatas, bisa dilihat bahwa hasil uji linearitas skor pretest dan posstest model pembelajaran Numbered Head Together dengan Deviation From Linearity yang menunjukkan nilai signifikasi 0,423 > 0,05 sehingga bisa disimpulkan kalau data mempunyai hubungan yang linear.

Tabel 9. Hasil Analisis Data menggunakan Uji Ancova
Descriptive Statistics

Dependent Variable: Posttest
\begin{tabular}{|l|r|r|r|}
\hline Model Pembelajaran & \multicolumn{1}{|c|}{ Mean } & \multicolumn{1}{|c|}{ Std. Deviation } & \multicolumn{1}{c|}{ N } \\
\hline TPS & 78,40 & 2,510 & 5 \\
NHT & 68,40 & 8,877 & 5 \\
Total & 73,40 & 8,099 & 10 \\
\hline
\end{tabular}

Sesuai dengan hasil analisis data menggunakan uji Ancova yang dilakukan pada model pembelajaran Think Pair Share memiliki jumlah arikel sebanyak 5 dengan rata-rata 78,40. Sedangkan pada model pembelajaran Numbered Head Together dengan jumlah artikel sebanyak 5 mempunyai rata-rata 68,40. Sehingga dari hasil tersebut terdapat perbedaan antara model pembelajaran Think Pair Share dan Think Pair Share ditinjau dari peningkatan hasil belajar pembelajaran tematik. Model pembelajaran Think Pair Share lebih tinggi dibandingkan dengan model pembelajaran Numbered Head Together.

\section{Tabel 10. Hasil Analisis Uji Ancova} Tests of Between-Subjects Effects

Dependent Variable: Posttest

\begin{tabular}{|l|r|r|r|r|r|r|}
\hline Source & $\begin{array}{r}\text { Type III Sum of } \\
\text { Squares }\end{array}$ & df & $\begin{array}{r}\text { Mean } \\
\text { Square }\end{array}$ & $F$ & $\begin{array}{r}\text { Sig. } \\
\text { Partial Eta } \\
\text { Squared }\end{array}$ \\
\hline Corrected Model & $250,000^{2}$ & 1 & 250,000 & 5,875 &, 042 &, 423 \\
Intercept & 53875,000 & 1 & 53875,600 & 1266,172 &, 000 &, 994 \\
Model_Pembelajaran & 250,000 & 1 & 250,000 & 5,875 &, 042 &, 423 \\
Error & 340,400 & 8 & 42,550 & & & \\
Total & 54466,000 & 10 & & & & \\
Corrected Total & 590,400 & 9 & & & & \\
\hline
\end{tabular}

a. $R$ Squared $=, 423$ (Adjusted $R$ Squared $=351$ )

Sesuai dengan hasil uji Ancova di atas, data $\mathrm{F}$ tabel yang di peroleh adalah 4,74. 4,74 didapat dengan menggunakan rumus df $2=n-k$, df $2=10-(2+1)$, df $2=10-3$, df $2=7$. Untuk menemukan hasil 4,74 terdapat pada $\mathrm{F}$ tabel yang disesuaikan berdasarkan jumlah sampel dikurang jumlah variabel (bebas dan terikat), sehingga ditemukanlah hasil yaitu 4,74.

Uji Hipotesis

Sesuai dengan hasil uji Ancova selanjutnya dilakukan uji hipotesis. Uji hipotesis dilakukan untuk menentukan apakah hipotesis penelitian in diterima atau ditolak. Berikut ini adalah hipotesis pada penelitian ini. 
$\mathrm{H}_{0} \quad$ : Tidak terdapat perbedaan yang signifikan ditinjau dari hasil belajar siswa SD pada pembelajaran tematik antara model pembelajaran Numbered Head Together dengan model pembelajaran Think Pair Share.

$\mathrm{H}_{\mathrm{a}} \quad$ : Terdapat perbedaan yang signifikan ditinjau dari hasil belajar siswa pada pembelajaran tematik antara model pembelajaran Numbered Head Together dan model pembelajaran Think Pair Share.

Kriteria pengambilan keputusan:

1. Menggunakan koefisien Sig. dengan keputusan:

a) Jika nilai Sig. Hitung (probabilitas) > 0,05 maka $\mathrm{H}_{0}$ diterima

b) Jika nilai Sig. Hitung (probabilitas) < 0,05 maka $\mathrm{H}_{\mathrm{o}}$ ditolak

Sesuai dengan perhitungan hipotesis dengan menggunakan uji Ancova melalui Univariate yang menunjukkan nilai signifikasi sebesar 0,042 yang berarti lebih kecil dari 0,05 $(0,042<0,05)$. Hasil uji Ancova membuktikan $\mathrm{f}$ hitung $>\mathrm{f}$ tabel yakni $5,875>4,74$ dan signifikasinya $0,042<0,05$ yang membuktikan bahwa $\mathrm{H}_{\mathrm{o}}$ ditolak dan $\mathrm{H}_{\mathrm{a}}$ diterima. Maka dari pernyataan diatas membuktikan bahwa terdapat perbedaan yang signifikan antara penggunaan model pembelajaran Think Pair Share dan Numbered Head Together. Walaupun kedua model pembelajaran tersebut sama-sama mempunyai pengaruh terhadap hasil pembelajaran tematik, akan tetapi model pembelajaran Think Pair Share lebih unggul dari model Numbered Head Together. Hal ini dapat dibuktikan melalui Hasil Analisis Data menggunakan Uji Ancova yang menunjukkan nilai rata-rata skor posstest model pembelajaran Think Pair Share sebesar 78,40 lebih unggul dari model pembelajaran Numbered Head Together sebesar 68,40. Kemudian, dilihat dari perbandingan data perolehan skor dari kedua model pembelajaran ini menunjukkan bahwa model pembelajaran Think Pair Share lebih unggul sebesar 17,48\% dari model pembelajaran Numbered Head Together yang memperoleh data skor sebesar 16,19\%. Maka dapat disimpulkan bahwa model pembelajaran Think Pair Share lebih efektif untuk meningkatkan hasil belajar pembelajaran tematik dibandingkan dengan model pembelajaran Numbered Head Together. Hasil ini memperkuat penelitian yang dilakukan oleh Indah Agusta, Maman Surahman dan M. Coesamin (2020). Yang menunjukkan bahwa model pembelajaran Think Pair Share lebih efektif dari model pembelajaran Numbered Head Together. Hal ini dapat dilihat dari nilai rata-rata posstest model pembelajaran Think Pair Share sebesar $83,92 \%$ sedangkan model pembelajaran Numbered Head Together sebesar 78,21\%.

Besarnya dampak yang diberikan oleh model pembelajaran Think Pair Share dan Numbered Head Together ditinjau dari hasil belajar pembelajaran tematik bisa dilihat dari hasil uji Effect Size.

Tabel 11. Interprestasi Effect Size

\begin{tabular}{cc}
\hline Effect Size & Interprestasi \\
\hline $0<\mathrm{d}<0,2$ & Kecil \\
\hline $0,2<\mathrm{d} \leq 0,5$ & Sedang \\
\hline $0,5<\mathrm{d} \leq 0,8$ & Besar \\
\hline $\mathrm{d}>0,8$ & Sangat Besar \\
\hline
\end{tabular}

Berikut ini adalah hasil analisis Effect Size yang dilakukan untuk melihat perbedaan antara Think Pair Share dan Numbered Head Together.

\section{Tabel 12 Uji Effect Size Menggunakan Uji Ancova}

\begin{tabular}{|l|r|r|r|r|r|r|}
\hline Dependent Variable: Posttest & $\begin{array}{c}\text { Type III Sum of } \\
\text { Squares }\end{array}$ & df & $\begin{array}{r}\text { Mean } \\
\text { Square }\end{array}$ & F & Sig. & $\begin{array}{r}\text { Partial Eta } \\
\text { Squared }\end{array}$ \\
\hline Corrected Model & $250,000^{2}$ & 1 & 250,000 & 5,875 &, 042 &, 423 \\
Intercept & 53875,600 & 1 & 53875,600 & 1266,172 &, 000 &, 994 \\
Model_Pembelajaran & 250,000 & 1 & 250,000 & 5,875 &, 042 &, 423 \\
Error & 340,400 & 8 & 42,550 & & & \\
Total & 54466,000 & 10 & & & & \\
Corrected Total & 590,400 & 9 & & & & \\
\hline
\end{tabular}

a. R Squared $=, 423$ (Adjusted R Squared $=351)$

Sesuai dengan tabel diatas melakukan uji Effect Size menggunakan uji Ancova menggunakan model pembelajaran Think Pair Share dan Numbered Head Together terdapat hasil yang terlihat pada kolom Corrected Model yang diketahui Partial Eta Squared sebesar 0,423 dengan nilai Sig. sebesar 0,042. 
Hal ini menunjukkan bahwa model pembelajaran Think Pair Share dan Numbered Head Together memberikan pengaruh tergolong sedang terhadap hasil belajar pembelajaran tematik.

\section{SIMPULAN}

Sesuai dengan hasil dan pembahasan yang telah dijelaskan, dapat disimpulkan kalau model pembelajaran Think Pair Share lebih tinggi dibandingkan dengan model pembelajaran Numbered Head Together ditinjau dari hasil belajar pembelajaran tematik. Hal ini bisa dibuktikan melalui uji Ancova yang menunjukan nilai rata-rata model pembelajaran Think Pair Share sebesar 78,40 nilai ini lebih tinggi dibandingkan dengan model pembelajaran Numbered Head Together yang memperoleh nilai sebesar 68,40. Berdasarkan penjelasan diatas, dapat disimpulkan bahwa terdapat perbedaan dari kedua model pembelajaran tersebut. Dimana model pembelajaran Think Pair Share lebih efektif ditinaju dari hasil belajar pembelajaran tematik.

Sesuai dengan perhitungan uji Effect Size yang diketahui Partial Eta Squared sebesar 0,423 dengan nilai Sig. sebesar 0,042. Hal ini menunjukkan bahwa model pembelajaran Think Pair Share dan Numbered Head Together memberikan pengaruh tergolong sedang terhadap hasil belajar pembelajaran tematik.

Manfaat penelitian ini ialah dapat memberikan kesempatan kepada guru untuk mengembangkan kreativitas cara mengajar secara lebih menarik bagi siswa sehingga dapat mengajak siswa untuk berperan aktif dalam proses pembelajaran serta guru dapat memperoleh gambaran mengenai model pembelajaran TPS (Think Pairs Share) dan NHT (Numbered Head Together) yang mempunyai pengaruh terhadap hasil belajar pembelajaran tematik siswa.

\section{SARAN}

Melihat dari simpulan di atas dapat dipahami bahwa penggunaan model pembelajaran Think Pair Share lebih efektif dibandingkan dengan model pembelajaran
Numbered Head Together dalam meningkatkan hasil belajar pembelajaran tematik. Oleh karena itu, peneliti menyarankan agar model pembelajaran Think Pair Share dapat dijadikan referensi oleh guru dalam proses pembelajaran di Sekolah Dasar terutama dalam meningkatkan hasil belajar pembelajaran tematik.

\section{DAFTAR PUSTAKA}

Agusta, I., Surahman, M., \& Coesamin, M. (2020). Pengaruh Model TPS dan Model NHT Terhadap Hasil Belajar Kelas V SD. Jurnal Pedagogi Unila.

Dachi, R. A. (2017). Proses dan Analisis Kebijakan Kesehatan (Suatu Pendekatan Konseptual). Yogyakarta: Deepublish.

Julianto dkk (2011) Teori Dan Implementasi Model-Model Pembelajaran

Inovatif, Surabaya: Unesa University Press

Komalasari, Kokom. 2010. Pembelajaran Kontekstual: Konsep dan Aplikasi. Refika Aditama. Bandung

Kartika, A. W., \& Harjono, N. (2020). Komparasi Model Pembelajaran Problem Based Learning dan Discovery Learning Ditinjau dari Peningkatan Kemampuan Pemecahan Masalah Matematika Siswa SD. Wahana Sekolah Dasar, 28(2), 42-50.

Purwanto. 2010. Evaluasi Hasil Belajar. Yogyakarta: Pustaka Pelajar.

Popiyanto, Y. (2020). Kooperatif Tipe Think Pair Share terhadap Hasil Belajar Tematik Siswa Sekolah Dasar. Trapsila: Jurnal Pendidikan Dasar, 1(01), 44-54.

Sudjana, Nana. (2010). Proses dan Hasil Belajar. Jakarta : Bumi Aksara.

Suyanto, 2013, Menjadi Guru Profesional strategi meningkatkan kualifikasi dan kualitas guru di Era Global, Jakarta : Erlangga

Trianto, 2010. Model Pembelajaran Terpadu. Jakarta: Bumi Aksara. 
Jurnal Ilmu Sosial dan Pendidikan

Vol. 4. No. 4 November 2020

http://ejournal.mandalanursa.org/index.php/JISIP/index

Terakreditasi Peringkat 5 (No. SK: 85/M/KPT/2020)

Tampubolon Saur. (2014). Penelitian

Tindakan Kelas Sebagai

Pengembangan Profesi Pendidik

dan Keilmuan. Jakarta: Erlangga.

Yanti, K. D., Parmiti, D. P., \& Suwatra, I. I. W. (2016). Pengaruh Model

Pembelajaran Kooperatif Tipe

Numbered Head Together (NHT)

terhadap Hasil Belajar

IPA. MIMBAR PGSD

Undiksha, 4(1). 